\title{
THE PECULIARITIES OF THE DAILY PHYSICAL ACTIVITY OF THE PUPILS OF THE GENERAL EDUCATIONAL INSTITUTIONS
}

\author{
Ivan Vaskan', Ludmila Vaschuk², Andriy Rostoka² \\ ${ }^{1}$ Yuriy Fedkovych Chernivtsi National University in Chernivtsi \\ ${ }^{2}$ Lesya Ukrainka East European National University in Lutsk
}

Vaskan I., Vaschuk L., Rostoka A., (2014) The peculiarities of the daily physical activity of the pupils of the general educational institutions. Health Problems of Civilization 2 (8), p. 31-34

\begin{abstract}
Summary: The peculiarities of the daily physical activity of the pupils of the general educational institutions of Ukraine are identified in the article. It is stressed that motor activity combines various motor actions and is defined by amount of movements performed by a person in the process of vital activity. For defining of daily motor activity it was used the methodology of timekeeping developed by scientists of Framingham State University for children and teenagers that is based on registration of human activity during a day. For defining the amount of time spent on each kind of motor activity, it was conducted a daily timekeeping of human activities: fixing of time spent on each kind in the succession as they alternated with each other.

It is determined that the juveniles' specially organized physical activity makes $0,33-0,44 \mathrm{hrs}$, it is by $65-70 \%$ lower than the hygiene standards. The indices of the daily physical activity of the 11-15-year-old pupils are 31,1-33,49 points. The mentioned index among boys is by $0,61-5,75 \%$ higher than among girls. Index of daily motor activity among girls increases till the age of 12, after that it decreases gradually. Among boys the highest level of physical activity is revealed at the age of 13-14, after that it is observed decreasing of the results. The level of the pupils' physical activity is determined by the traditions of physical culture at school, by the available material resources, by the level of the professional skills of the teachers of physical culture, educationalists, school authorities.
\end{abstract}

Key words: physical activity, daily physical activity, pupils, general educational institutions

\section{Introduction}

The physical activity combines various motion actions performed in everyday life and labour activity. It plays an important role in the optimal functioning of the person's organism and it is the basis of healthy life (Apanasenko, 1998; Baj - Korpak et al. 2010; Bergier J. et al 2011; Bergier et al. 2012; Cabak, Woynarowska, 2004; Korpak, Bergier, 2011). The physical activity is determined by the amount of actions performed by the person during the process of his vital activity (Krycevuch 2010). At the same time the modern level of the physical activity of the majority of pupils of Ukraine does not correspond to the physiological standards which provide the proper level of the children and juveniles' physical state (Gorobej 1994). The pupils' motion regime makes only 3-4 hours per week at the rate of 2022 . The juveniles' daily necessity in actions is complied at the average by 18-22\%, that's why the deficiency makes about 80\%. Every fifth child of school age and every tenth student has the sufficient level of the curative physical activity. It is one of the lowest indices in Europe. It is caused by the defects of the physical training lessons, low efficiency of out-of-school work, lack of interest in doing physical exercises independently (Bylatova 2008).

The deficiency of the physical activity affects on the children and juveniles' health adversely (Balsevuch, 1987). The problem of compensation of the negative effects of the deficiency of the physical activity by the means of the pupils and students' physical training is still prevailing in the researches of a number of physical training specialists outside Ukraine (Bergier et al. 2010; Biernat et al. 2007; Gacek, 2003).

While measuring the physical activity, the scientists use different criteria and methods which enable us to obtain objective data and we don't need multiplex equipment.

Address for correspondence: Ivan Vaskan,Yuriy Fedkovych Chernivtsi National University, 2 Kotsjubynskyi Str.Chernivtsi 58012, Ukraine
e-mail science-vnu@ukrnet, phone: +380-372-526235

Tables: 1, Figures: 2, References: 14, Full text PDF www.hpc.edu.pl Copyright (C) Pope John Paul II State School of Higher Education In Biała Podlaska, Sidorska 95/97, 21-500 Biała Podlaska Indexation: Index Copernicus, Polish Ministry of Science and Higher Education. This is an open-access article distributed under the terms of the Creative Commons Attribution Non-commercial License (http://creativecommons.org/licenses/by-nc/3.0), which permits use, distribution, and reproduction in any medium, provided the original work is properly cited, the use is non-commercial and is otherwise in compliance with the license. 
The duration of the motion component in a daily "budget" of time which is either a unit of time (in minutes, hours) or in per cents relatively to the duration of a day ( 24 hours) belong to the criteria and methods. For the last years the continuous recording of heartbeat and the determination of sphygmic "value" of different kinds of actions including the total quantity of the physical activity in a day has been widely used (Krucevuch 2010).

The methodology of timing is based on the recording the kinds of the person's activity during a day. It lets us obtain all the information about the duration of the certain type of activity, rest, physical exercise, etc. Such a range of options lets us describe this methodology of timing as objective, accurate and informative.

The aim of the research is to identify the peculiarities of the physical activity of the pupils of the general educational institutions.

The methods and structure of the research. The methodology of timing which was worked out by the scientists of Freming University For Children and Juveniles, founded for recording the person's activity during a day, was used for identifying the daily physical activity (Krycevuch 2010). The following levels of the physical activity among juveniles are singled out:

$\square$ basic level (BL) - sleep, rest lying;

$\square$ sedentary level (SL) - a trip by some vehicle, reading, drawing, watching TV, table and computer games, meals;

$\square$ low level (LL) - personal hygiene, lessons at school (except physical and manual trainings), walking;

mean level (ML) - homework, walks, morning exercises, active breaks at school;

$\square$ high level (HL) - plenty of physical exercises during specially organized lessons, active games, running, sledging, skating, cycling, skiing, scootering, roller skating, etc.

The daily timing of the kinds of the person's activity was conducted to determine the amount of time spent for every kind of the physical activity: we fixed the duration spent for every kind of the activity in the sequence of its interchange. Using Freming methodology of defining the daily physical activity on the basis of timing of different levels of the pupils' physical activity during a day we are permitted to compare these indices among 11-15-yearold juveniles.

The results of the research and their analysis. The results of the research indicate that the structure of the girls' daily physical activity consists of the basic level (8,31-8,58 hrs), the sedentary level $(6,27-6,49 \mathrm{hrs})$, the low level $(6,17-6,58 \mathrm{hrs})$, the mean level $(2,32-2,52 \mathrm{hrs})$ and the high level $(0,33-0,4 \mathrm{hrs})$. These indices among boys are similar. In particular, the basic level makes 8,42-8,55 hrs, the sedentary level 6,29-5,3 hrs, the low level 6,37-7,22 hrs, the mean level 2,47-2,57 hrs and the high level 0,36-0,47 hrs. In general the indices of the high and low levels of the physical activity among boys are a little higher (table 1 ).

The specially organized physical activity which corresponds to the high level of the activity in our research includes various forms of physical exercises, going home and to school, walks. Daily two-hour range of motions which would provide the physiological necessity of organism in physical activity is recommended to the pupils.

Table 1. The structure of the juveniles' daily physical activity, hrs

\begin{tabular}{|l|c|c|c|c|c|c|}
\hline \multirow{2}{*}{ The level of the physical activity } & \multirow{2}{*}{ SSex } & \multicolumn{5}{|c|}{ Age, year-old } \\
\cline { 4 - 7 } & & 11 & 12 & 13 & 14 & 15 \\
\hline \multirow{3}{*}{ Basic } & GG & $8,49 \pm 0,03$ & $8,42 \pm 0,04$ & $8,31 \pm 0,05$ & $8,58 \pm 0,04$ & $8,43 \pm 0,05$ \\
\hline & BB & $8,42 \pm 0,04$ & $8,55 \pm 0,03$ & $8,49 \pm 0,04$ & $8,53 \pm 0,05$ & $8,47 \pm 0,05$ \\
\hline \multirow{3}{*}{ Sedentary } & GG & $6,33 \pm 0,32$ & $6,5 \pm 0,37$ & $6,49 \pm 0,36$ & $6,27 \pm 0,43$ & $6,27 \pm 0,54$ \\
\hline & BB & $6,29 \pm 0,37$ & $6,14 \pm 0,29$ & $5,33 \pm 0,33$ & $5,3 \pm 0,37$ & $5,54 \pm 0,45$ \\
\hline \multirow{3}{*}{ Low } & GG & $6,35 \pm 0,41$ & $6,17 \pm 0,36$ & $6,44 \pm 0,39$ & $6,48 \pm 0,42$ & $6,58 \pm 0,34$ \\
\hline \multirow{3}{*}{ Mean } & BB & $6,48 \pm 0,35$ & $6,37 \pm 0,25$ & $7,19 \pm 0,31$ & $7,22 \pm 0,29$ & $7,14 \pm 0,36$ \\
\hline \multirow{2}{*}{ High } & GG & $2,48 \pm 0,21$ & $2,52 \pm 0,24$ & $2,36 \pm 0,29$ & $2,32 \pm 0,18$ & $2,39 \pm 0,24$ \\
\hline & BB & $2,51 \pm 0,33$ & $2,57 \pm 0,27$ & $2,55 \pm 0,31$ & $2,48 \pm 0,25$ & $2,47 \pm 0,19$ \\
\hline \multirow{2}{*}{ The index of the physical activity, points } & GG & $0,35 \pm 0,04$ & $0,39 \pm 0,05$ & $0,40 \pm 0,04$ & $0,35 \pm 0,04$ & $0,33 \pm 0,03$ \\
\hline & BB & $0,36 \pm 0,04$ & $0,37 \pm 0,04$ & $0,44 \pm 0,05$ & $0,47 \pm 0,03$ & $0,38 \pm 0,05$ \\
\hline & GG & $32,68 \pm 0,43$ & $32,82 \pm 0,47$ & $32,77 \pm 0,33$ & $31,67 \pm 0,42$ & $32,58 \pm 0,38$ \\
\hline
\end{tabular}

In general the dynamics of the specially organized physical activity are shown in figure 1. 


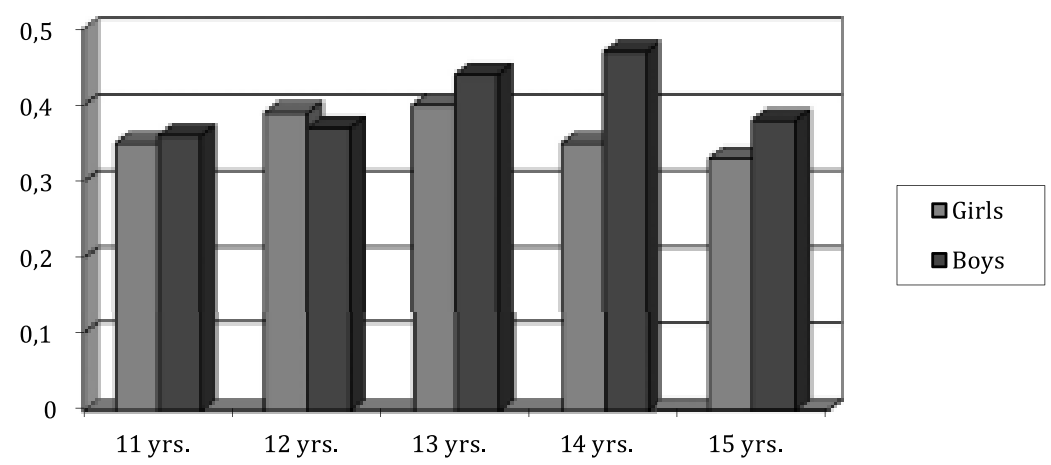

Figure 1. Age dynamics of the juveniles' specially organized physical activity

In different age periods the level of the organized activity varies. The juveniles' specially organized physical activity makes $0,33-0,44 \mathrm{hrs}$ in school practical physical trainings. This index is by $65-70 \%$ lower than the hygiene standard.

In order to calculate the index of the juveniles' daily physical activity the amount of hours spent for every kind of activity multiplied by the weighting factor of a certain activity. On the basis of scaling the indices of every kind of the physical activity and the index of the daily physical activity were obtained (Figure 2.).

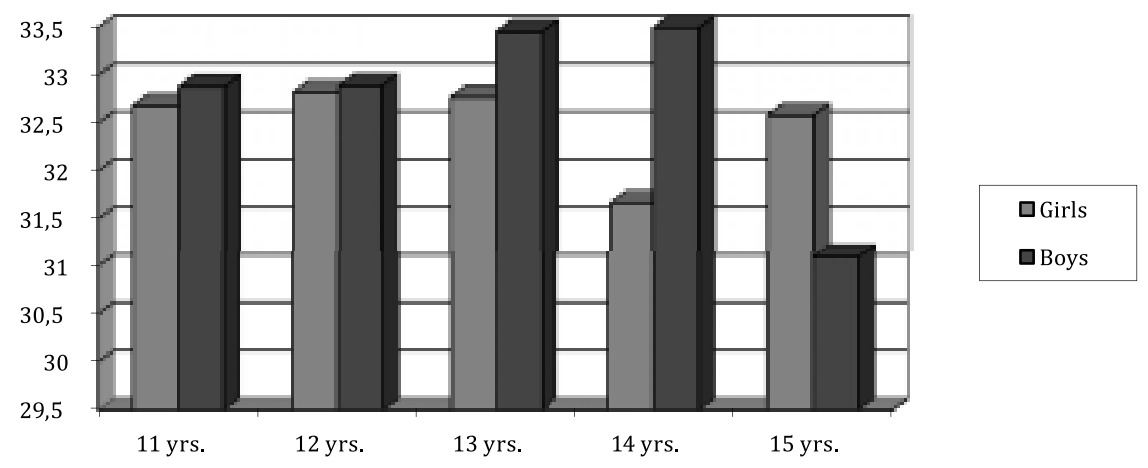

Figure 2. Dynamics of the index of the juveniles' daily physical activity

In general the indices of the daily physical activity of the 11-15-year-old pupils are 31,1-33,49 points. The mentioned index among boys is by $0,61-5,75 \%$ higher than among girls. The largest difference is among 13-14-year-old juveniles.

The analysis of the results of the research shows the marginal changes in the dynamics of the index of the physical activity of juveniles of different age groups. The index of the daily physical activity among girls increases up to 12 years, then it begins to decrease gradually. The highest level of physical activity among boys is detected in the age of 13-14 years, then the results decrease. We can assume that decreasing of the physical activity is connected with the reduction of the pupils' motivation and interest in physical culture.

The analysis of the results of the research shows that the traditions of physical culture at school influence upon the level of the pupils' physical activity, the available material resources, the level of the professional skills of the teachers of physical culture, educationalists and school authorities. It is also connected with the underestimation of the curative and educational role of physical culture and with our incomprehension that the physical activity depends upon us to a great extent.

It is determined by the scientific works that the training effect is at a high level of the physical activity. The organizational physical training lessons and intensive sport and outdoor games belong to this level. At the same time this component of the physical activity is appropriate to the overwhelming majority of juveniles only in the form of compulsory lessons of physical culture. If there is no lesson on a certain day, so the high level of the physical activity is lacking.

Having defined the level of the juveniles' physical activity, it can assumed that it is scarce and it doesn't assist in keeping the proper functional body state.

Conclusion. In the result of the research it is determined that the juveniles' specially organized daily physical activity makes $0,33-0,44 \mathrm{hrs}$, it is by $65-70 \%$ lower than the hygiene standard. The indices of the daily physical activity of the 11-15-year-old pupils are $31.1-33,49$ points. The mentioned index among boys is by $0,61-5,75 \%$ higher than among girls. 
The level of the pupils' physical activity is determined by the traditions of physical culture at school, by the available material resources, by the level of the professional skills of the teachers of physical culture, educationalists, school authorities.

\section{References:}

1. Апанасенко Г. Л. (1998), Медицинская валеология / Г. Л. Апанасенко, Л. А. Попова. - Киев : Здоровья, - 246 с.

2. Baj-Korpak J., Soroka A., Korpak F. (2010), Aktywnosc fizyczna wybranych grup spoleczno-zawodowych (wszkolnictwie). Człowiek i Zdrowie, Nr 1 (IV): 152-161.

3. Бальсевич В. К. (1987), Физическая активность человека / В. К. Бальсевич, В. А. Запоржанов. - Киев : Здоровья, - 224 с.

4. Bergier J., Bergier B., Soroka A., Kubinska Z. (2010), Aktywność fizyczna pielęgniarek z uwzględnieniem ich wieku. (Physical activity of nurses with consideration of their age). Medycyna Ogólna 16 (XLV): 595-605 (in Polish).

5. Bergier J., Kubicska Z., Bergier B. (2011), Nurses ' physical activity with respect to their education. Turystyka i Rekreacja, nr 8.

6. Bergier J., Bergier B., Tsos A. (2012), Physical activity and sedentary lifestyle of female students from Ukraine. Human and Health. Issue 2.Volume VI: 131-137.

7. Biernat E., Stupnicki R., Gajewski A.K (2007), Międzynarodowy kwestionariusz aktywności fizycznej (IPAQ) wersja polska. Wych. Fiz. Sport:51: 47-54.

8. Булатова М. М. (2008), Сучасні фізкультурно-оздоровчі технології у фізичному вихованні / М. М. Булатова, Ю. А. Усачов // Теорія і методика фізичного виховання; за ред. Т. Ю. Круцевич. - К. : Олімпійська л-ра, - С. 320-354.

9. Cabak A., Woynarowska B. (2004), Aktywność fizyczna młodzieży w wieku 11-15 lat w Polsce i w innych krajach w 2002 roku. Wychowanie Fizyczne i Sport, 4, 355-366.

10. Gacek M. (2003), Poziom aktywności ruchowej młodzieży akademickiej w Krakowie. Kultura Fizyczna, 5-6.

11. Горобей М. П. (1994), Педагогічні умови активізації рухової діяльності молодших школярів у режимі продовженого дня : автореф. дис. на здобуття наук. ступеня канд. пед. наук : спец. 13.00.01 “Теорія та історія педагогіки" / М. П. Горобей. - К., -22 с.

12. Korpak F., Bergier J. (2011), Aktywność fizyczna uczniów klas drugich I LO w Białej Podlaskiej. Wychowanie Fizyczne i Zdrowotne nr 1.

13. Круцевич Т. Ю. (2010), Рекреація у фізичній культурі різних груп населення / Т. Ю. Круцевич, Г. В. Безверхня. - К. : Олімпійська л-ра, - 248 с.

14. Сухарев А. Г. (1976), Двигательная активность и здоровье подрастающего поколения / Сухарев А. Г. - М.: Знание, - 63 с. 